\title{
A new approach to chemical modification protocols of Aspergillus niger and sorption of lead ion by fungal species
}

\author{
Omotayo Rafiu Awofolu* \\ Department of Environmental Sciences \\ Faculty of Natural Science \\ Tshwane University of Technology \\ P. Bag X680 Pretoria 0001 \\ South Africa \\ Tel: 27123186115 \\ Fax: 27123186354 \\ E-mail: AwofoluOR@tut.ac.za \\ Jonathan Okechukwu Okonkwo \\ Department of Environmental Sciences \\ Faculty of Natural Science \\ Tshwane University of Technology \\ P. Bag X680 Pretoria 0001 \\ South Africa \\ Tel: 27123826245 \\ Fax: 27123826354 \\ E-mail: Okonkwooj@tut.ac.za

\section{Renate Roux-Van Der Merwe} \\ Department of Food Technology and Microbiology \\ Faculty of Natural Science \\ Tshwane University of Technology \\ P. Bag X680 Pretoria 0001 \\ South Africa \\ Tel: 27123826240 \\ Fax: 27123826256 \\ E-mail: RouxVanDerMerweMP@tut.ac.za \\ Jackie Badenhorst \\ Department of Food Technology and Microbiology \\ Faculty of Natural Science \\ Tshwane University of Technology \\ P. Bag X680 Pretoria 0001 \\ South Africa \\ Tel: 27123826242 \\ Fax: 12273826256 \\ E-mail: BadenhorstJ@tut.ac.za

\section{Erika Jordaan} \\ Department of Food Technology and Microbiology \\ Faculty of Natural Science \\ Tshwane University of Technology \\ P. Bag X680 Pretoria 0001 \\ South Africa \\ Tel: 27123826356 \\ Fax: 27123826256 \\ E-mail: JordaanE@tut.ac.za
}

Financial support: Fellowship awarded to Dr O.R. Awofolu by Tshwane University of Technology Pretoria, South Africa.

Keywords: Aspergillus niger, fungi species, lead ion, modification, sorption.

Abbreviations: CBS: Central Bureau for Schimmel Culture

EDTA: ethylenediamine tetra acetic acid

FAAS: Flame Atomic Absorption Spectrophotometry

MEA: Malt Extract Agar

\footnotetext{
* Corresponding author
} 
Biomasses of five fungi species (Aspergillus niger, Penicillium austurianum, Saccharomyces cerevisiae, Mucor arcindloides and Trichoderma reesi were evaluated for their uptake of lead ion from aqueous solution using batch systems. Both dead and live fungal biomasses were comparatively studied for their adsorption efficiencies. The effect of $\mathrm{pH}$ as one of the primary factors that influences sorption efficiency of metal ions in solution was also studied. Modification of the fungal biomass with the least sorption capacity was carried out using a four-step procedure. Three different modifying agents under the optimised experimental conditions were used. The percentage uptake of lead ion by fungi species ranged from: Aspergillus niger: 6.7164.95\% and 66.91-95.27\%; Penicillium austurianum: 44.47-98.85\% and 75.57-94.21\%; Saccharomyces cerevisiae: $52.61-88.68 \%$ and $61.20-89.95 \%$; Mucor arcindloides: $83.78-93.13 \%$ and $62.91-97.65 \%$ and Trichoderma reesi: $52.52-80.70 \%$ and $35.31-88.13 \%$ for dead and live biomass respectively. The influence of $\mathbf{p H}$ on metal uptake was evaluated at $\mathrm{pH}$ of 2, 4, 6 and 7. A regular pattern of sorption efficiency among the dead fungi species with respect to $\mathrm{pH}$ was observed and the $\%$ adsorption decreased in the order $\mathrm{pH} 7>2>6>4$ with the exception of Mucor (pH $7>2>4>6$ ). Modified biomass of Aspergillus niger with oxalic acid, malic acid and ethylenediamine tetraacetic acid (EDTA) recorded $\mathbf{9 2 . 8 4 \%}, \mathbf{4 8 . 1 1 \%}$ and $39.83 \%$ uptake of $\mathrm{Pb}$ respectively which correspond to $69.65 \%, 41.23 \%$ and $29.25 \%$ increase when compared to $28.18 \%$ of the unmodified biomass. These quantitative adsorptions demonstrate the potential application of modified biomass for the removal of $\mathrm{Pb}$ ion from aqueous solution.

The removal and remediation of toxic metals from aqueous streams is imperative especially in countries where potable water is in short supply such as South Africa. The presence of toxic metals such as $\mathrm{Pb}, \mathrm{As}, \mathrm{Hg}$ and $\mathrm{Cd}$ in the environment is of great concern due to their health implications. They are non-essential metals with no physiological benefits to man and wildlife (Tyler, 1981; Borgmann, 1983). Over the years, anthropogenic activities have greatly increased the level of these toxic metals especially in aqueous systems, hence efficient and cost effective methods are being sought for their removal.

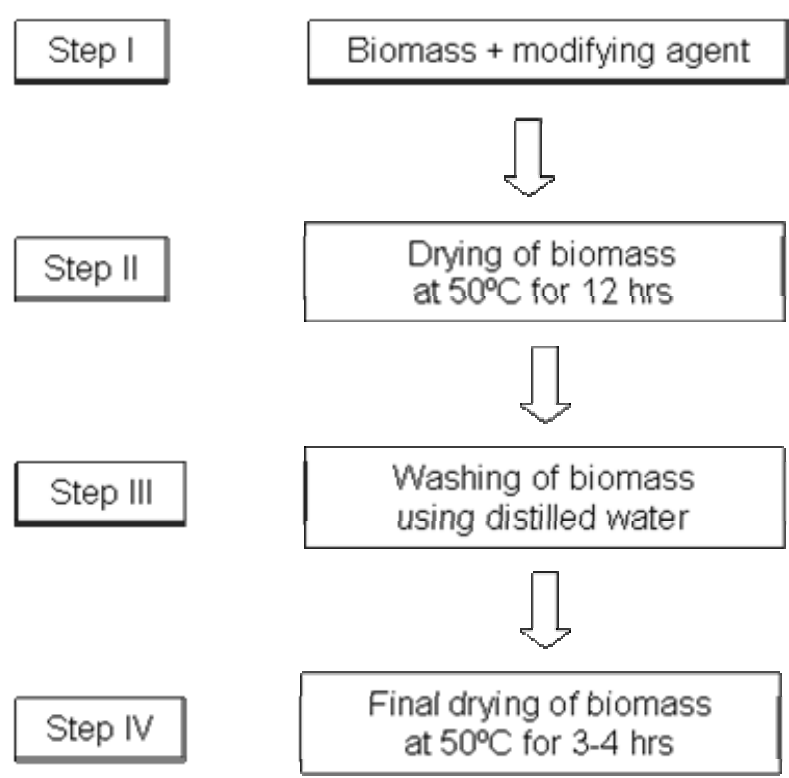

Figure1. A four-step modification protocol of fungal biomass.

Conventional physical and chemical methods of metal removal from aqueous streams that have been applied include chemical precipitation, ion-exchange, adsorption and electrochemical techniques (Reed and Nonavinakere, 1992; Atwood et al. 2002; Di Palma et al. 2003). These methods are plagued with incomplete removal, involve the use of large volume of chemicals, high costs especially when contaminant concentrations are in the range of 10-100 $\mathrm{mg} \mathrm{l}^{-1}$, laborious and generate other wastes that require further disposal (Peters et al. 1985; Rostami and Joodaki, 2002).

Recent advances towards effective treatment methods for the removal of heavy metals in aqueous media involve the use of microorganisms (Viraraghavan and Yan, 2003; Cañizares-Villanueva et al. 2004; Ma et al. 2004). Attention has been focused lately on the application of fungal species for metal removal from aqueous media (Huang and Huang, 1996; Zouboulis et al. 2004; González-Chávez et al. 2004). Fungal cells, both living and dead such as Aspergillus, Penicillium, Rhizopus, and Saccharomyces have been applied to metal removal from aqueous streams using either

Table 1. Uptake of $\mathrm{Pb}$ ion by unmodified and modified Aspergillus niger biomass at $\mathrm{pH}$ 7. Mean of triplicate analysis; $\mathrm{Pb}$ concentration $100 \mathrm{mg} \mathrm{I}^{-1}$; biomass loading at $0.3 \mathrm{~g}$; EDTA: ethylenediamine tetra acetic acid.

\begin{tabular}{|c|c|c|c|}
\hline $\begin{array}{c}\text { \% metal uptake } \\
\text { (unmodified biomass) }\end{array}$ & Modifying agents & $\begin{array}{c}\text { \% metal uptake } \\
\text { (modified biomass) }\end{array}$ & $\begin{array}{c}\text { \% increase } \\
\text { in metal uptake }\end{array}$ \\
\hline 28.18 & Oxalic acid & 92.84 & 69.65 \\
\hline & Malic acid & 48.11 & 41.23 \\
\hline & EDTA & 39.83 & 29.25 \\
\hline
\end{tabular}


batch or continuous modes (Rostami and Joodaki, 2002; Matis et al. 2003; Park et al. 2005). However, the use of dead cells has received greater attention compared to living ones. This is due to the argument that dead cells do not have toxicity limitations, no requirement of growth and nutrient media and easy desorption of adsorbed metal ions.

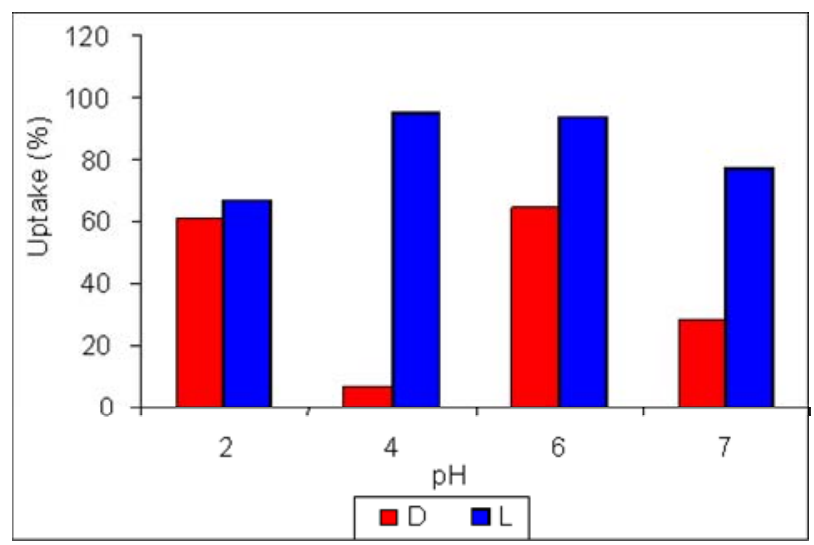

Figure 2. Effect of $\mathrm{pH}$ on uptake of $\mathrm{Pb}$ by Aspergillus niger. $\mathrm{Pb}$ concentration $100 \mathrm{mg} \mathrm{l}^{-1}$; biomass loading, $0.3 \mathrm{~g} ; \mathrm{D}=$ dead biomass, $\mathrm{L}=$ live biomass.

Generally however, the efficiency of fungal cells as sorbents varies greatly and depends on the physiological states, surface properties of cells, $\mathrm{pH}$ and other physicochemical parameters of the metal solution (Sag and Kutsal, 1996). The ability of microbial cells to bind metals from aqueous solutions has been demonstrated to be a function of solution $\mathrm{pH}$ (Wilhelmi and Duncan, 1995). In addition, metal ion adsorption on both non-specific and specific sorbents is $\mathrm{pH}$ dependent, as the $\mathrm{pH}$ affects the availability of metal ions in solution (speciation), as well as the metal binding sites onto cell surface (Zouboulis et al. 2004).

In an attempt to increase sorption efficiencies, fungal biomasses have been modified using varieties of modifying agents (Brady and Duncan, 1994; Matis et al. 2003). Fungal cell walls are made up of polysaccharides and proteins which contain many functional groups such as carboxyl, hydroxyl, phosphates and amino groups that can bind with metal ions (Veglio and Beolchini, 1997). Hence, the performance of an adsorbent depends on its surface properties as governed by the chemical structure, hydrophobic and hydrophilic characters of the cell wall. Biosorption mechanisms generally involve passive sequestration of metals by cell wall through processes of adsorption, ion-exchange, complexation, etc.

Several modification protocols of fungal biomasses using different modifying reagents have been reported (Brady and Duncan, 1994; Jianlong, 2002; Matis et al. 2003; Deng and Ting, 2005). These protocols, however involve complex and time consuming processes such as long chemical reaction steps, centrifugation, dialysis, specific reaction conditions (reaction under nitrogen) and multiple washing and re-suspension of biomass which might even contribute to poor performance of the modified biomass.

In this study, live and dead fungal biomasses of five fungi species - Aspergillus niger, Penicillium austurianum, Saccharomyces cerevisiae, Mucor arcindloides and Trichoderma reesi were evaluated for their sorption efficiencies of lead ion from aqueous solution using batch systems. A toxic metal of environmental significance (lead) was used as the test metal. The effect of $\mathrm{pH}$ as one of the primary factors that influences sorption efficiency of metal ions in solution was also studied since it is a key parameter in most biological processes and controls the growth and/or the adsorption capacity of substances. In order to eliminate the lengthy steps outlined in some of the aforementioned protocols, a new four-step approach to the modification procedure of the biomass of Aspergillus niger was investigated. The four-step approach involved: surface modification of biomass with suitable agents. This was followed by drying, washing and finally drying. Modification of the biomass (Aspergillus niger) with the least sorption capacity was carried out using three simple and cost effective modifying agents under the optimised experimental conditions.

\section{MATERIALS AND METHODS}

\section{Reagents and instrument}

All reagents used were of analytical grades. $1000 \mathrm{mg} \mathrm{l}^{-1}$ of lead standard stock solution (AAS grade) was prepared from reagent grade $\mathrm{Pb}\left(\mathrm{NO}_{3}\right)_{2}$ purchased from Heyns Laboratory; Fonteinbleau, South Africa. Working standard solutions were prepared by dilution of the stock. Deionised

Table 2. Comparison of $\%$ metal uptake results of some metals from the selected literature by various biosorbents.

\begin{tabular}{|c|c|c|c|c|}
\hline \multicolumn{1}{|c|}{ Biosorbent } & \multicolumn{3}{|c|}{ (\%) uptake } & References \\
\hline & UMB a & MB b & Metal ion & \\
\hline Spirulina maxima & 84 & 92 & $\mathrm{~Pb} \mathrm{2+}$ & Liu et al. 2005 \\
\hline Lentinus sajor-caju & 50 & 60 & $\mathrm{Cr} \mathrm{6+}$ & Bayramoglu et al. 2005 \\
\hline Penicillium chrysogenum & 22 & 76.3 & $\mathrm{~Pb} \mathrm{2+}$ & Deng and Ting, 2005 \\
\hline Aspergillus niger & 28.18 & 92.84 & $\mathrm{~Pb} \mathrm{2+}$ & This study \\
\hline
\end{tabular}

a) UMB: Unmodified biomass

b) MB: Modified biomass. 
water from Millipore Instrument Corporation was used throughout the study. Portable hand-held combo (HI 98830) from Hanna Inc. was used for $\mathrm{pH}$ measurements. A Perkin Elmer AA 3030 Flame Atomic Absorption Spectrometer (FAAS) equipped with automatic background corrector was used for all trace metal determinations.

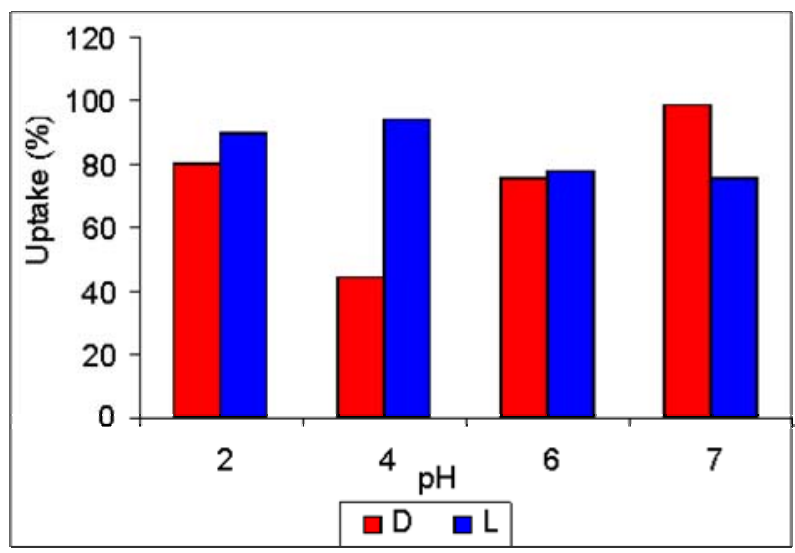

Figure 3. Effect of $\mathrm{pH}$ on uptake of $\mathrm{Pb}$ by Penicillium austurianum . $\mathrm{Pb}$ concentration, $100 \mathrm{mg} \mathrm{I}^{-1}$, biomass loading at $0.3 \mathrm{~g}, \mathrm{D}=$ dead biomass, $\mathrm{L}=$ live biomass.

\section{Microorganisms and growth media}

The experiments described in this study were carried out using five different species of fungi. These are Aspergillus niger (TUTC 120), Penicillium sp (TUTC 077), Saccharomyces cerevisiae (TUTC 112), Mucor circinelloides f. circinelloides (CBS 106.18) and Trichoderma reesi (TUTC 101). They were maintained on Malt Extract Agar (MEA).

\section{Cultivation of fungi species for biomass production}

Each of the five fungal species were grown on MEA plates for approximately 4 days or until the plates were fully grown. A $10 \%$ inoculum of spores or cellswas transferred to 11 Erlenmeyer flasks containing the cultivation medium. For the transfer of fungal cultures, about $20 \mathrm{ml}$ of the spore buffer solution ( $\mathrm{pH}$ 6.0) was added to a Petri dish containing fungal growth. Sterile Dragalsky needle was used to transfer the spores or yeast cells into the buffer solution. The buffer solution, consisting of $0.05 \mathrm{M}$ solution of $\mathrm{KH}_{2} \mathrm{PO}_{4} \mathrm{l}$ and $8.0 \times 10^{-4 \mathrm{M}}$ of Tween 80 (Polyoxyethylene Sorbitan Monooleate was adjusted to $\mathrm{pH} 6.0$ with $1 \mathrm{~N}$ $\mathrm{NaOH}$ and the solution sterilised by autoclaving at $121^{\circ} \mathrm{C}$ for 15 min.

After inoculation, the organisms were grown at $25^{\circ} \mathrm{C}$ and $140 \mathrm{rpm}$ for three days. Each flask contained $300 \mathrm{ml}$ sterile cultivation medium ( $\mathrm{pH} \mathrm{6.0)}$ that consisted of $\left(\mathrm{g} \mathrm{l}^{-1}\right)$ : citric acid, 0.15; $\left(\mathrm{NH}_{4}\right)_{2} \mathrm{SO}_{4}, 2.50 ; \mathrm{MgSO}_{4} .7 \mathrm{H}_{2} \mathrm{O}, 0.50 ; \mathrm{KH}_{2} \mathrm{PO}_{4}$, 6.00; $\mathrm{CaCl}_{2} .2 \mathrm{H}_{2} \mathrm{O}, 0.04$; yeast extract, 3.00 ; and glucose, 20.00. The medium was prepared by placing $300 \mathrm{ml}$ of distilled water in $2 \mathrm{l}$ Erlenmeyer flask and then citric acid, $\left(\mathrm{NH}_{4}\right)_{2} \mathrm{SO}_{4}, \mathrm{MgSO}_{4} .7 \mathrm{H}_{2} \mathrm{O}, \mathrm{KH}_{2} \mathrm{PO}_{4}, \mathrm{CaCl}_{2} \cdot 2 \mathrm{H}_{2} \mathrm{O}$, yeast extract, and glucose were added. Additional $400 \mathrm{ml}$ of distilled water was poured into the flask and the medium was aseptically dispensed into 11 Erlenmeyer flasks and sterilized by autoclaving at $121^{\circ} \mathrm{C}$ for $15 \mathrm{~min}$.

\section{Harvesting of fungal biomasses}

After the cultivation was completed, the fungal cells were harvested by filtration through Whatman number 1 filter paper and washed with $100 \mathrm{ml}$ of distilled water. Half of the cells were immediately frozen at $-70^{\circ} \mathrm{C}$ after which all the cultures were transferred to a freeze dryer for $48 \mathrm{hrs}$. The fungal cells were removed from the freeze dryer and stored in a freezer at $-70^{\circ} \mathrm{C}$. The remaining half of the harvested cells were autoclaved to obtain dead biomass after which the same procedure was followed, namely freeze drying and storing of the cells. Freeze-dried fungal biomasses were pulverised in clean acid washed mortar and pestle and then passed through $0.45 \mu \mathrm{m}$ sieve. All optimisations were based on the fine powdered biomass obtained.

\section{Incubation of fungal biomasses with metal ion}

Working standard of lead ion was prepared from $1000 \mathrm{mg} \mathrm{l}$ ${ }^{-1}$ stock solution. $100 \mathrm{ml}$ of $100 \mathrm{mg} \mathrm{l}^{-1}$ of lead standard was placed in glass stopper $250 \mathrm{ml}$ Erlenmeyer flask and the solution $\mathrm{pH}$ was adjusted accordingly. $\mathrm{pH}$ range of 2, 4, 6 and 7 were evaluated for their influence on metal adsorption. $0.3 \mathrm{~g}$ of the powdered biomass was added to the flask and the cell suspension was adequately mixed by incubating and agitating at $150 \mathrm{rpm}$ for $24 \mathrm{hrs}$ at $25^{\circ} \mathrm{C}$. All experiments were carried out in triplicate.

\section{Metal determination}

Fungal suspension was filtered using $0.45 \mu \mathrm{m}$ membrane filter and the remaining non-adsorbed lead ion in cell-free filtrate was determined using FAAS. Good linearity of the calibration standards was obtained and triplicate analysis of each sample was carried out together with blank analysis. The amount of metal taken up by the biomass was calculated as the difference between the initial and final concentration of the metal in the aqueous solution.

\section{Chemical modification of fungal biomass}

Modification of the biomass of Aspergillus niger was carried out using three simple and cost effective reagents, oxalic acid, malic acid and ethylenediamine tetraacetic acid (EDTA). About $1 \mathrm{~g}$ of powdered biomass were separately placed in three clean $10 \mathrm{ml}$ beakers and slightly moistened with deionised water. $7 \mathrm{ml}$ of $0.05 \mathrm{M}$ solution of EDTA, $0.1 \mathrm{M}$ solution of oxalic and malic acids were separately added to each of the three beakers respectively. The acid/slurry was dried in the oven at $50^{\circ} \mathrm{C}$ overnight. The modified dried biomasses were then washed with $20 \mathrm{ml}$ of 
distilled water to remove unreacted acid until the $\mathrm{pH}$ of the filtrate was near neutral. The modified biomass were again dried at $50^{\circ} \mathrm{C}$ for $6 \mathrm{hrs}$, allowed to cool and then gently stirred with glass rod to return them to powdery form. $0.3 \mathrm{~g}$ of the modified biomasses was taken through metal adsorption and determination protocols at $\mathrm{pH} 7$ as described earlier.

\section{RESULTS AND DISCUSSION}

\section{Batch experimental study with $\mathrm{pH}$}

In this study, batch experimental systems were used in the optimization of metal sorption by fungal biomasses with respect to $\mathrm{pH}$. Several literatures have reported the optimization of parameters such as adsorption time, metal concentrations, duration of agitation, effects of other ions in solution etc with respect to adsorptive capacity and efficiency of biosorbents (Thomas et al. 2000; Aldrich and Feng, 2004; Iqbal et al. 2005). In many of these studies, similar patterns of experimental findings were reported with respect to these parameters. For example, the adsorption kinetics usually follow an initial rapid increase in sorption pattern followed by a slow process; biosorption capacity of individual metal ion is reduced in the presence of other metal ions, increase in metal removal as biomass concentration increases (Natarajan et al. 1998; Yin et al. 1999; Viraraghavan and Guangyu, 2003; Park et al. 2005).

In this study however, emphasis was placed on the influence of $\mathrm{pH}$ on metal adsorption by biosorbent. $\mathrm{pH}$ has been reported as a key parameter in most biological processes and controls the growth and/or the adsorption capacity of substances (Crist and Martin, 1999; Wei and Tobin, 2004). In addition, solution $\mathrm{pH}$ influences the adsorption of metals differently.

Results of sorption efficiency by both live and dead biomass of each of the evaluated fungi species are presented in Figure 2, Figure 3, Figure 4, Figure 5, and Figure 6. In Figure 2, the percentage uptake of lead ion by Aspergillus niger ranged from 6.71-64.95\% and 66.91$95.27 \%$ for dead and live biomass respectively across optimised $\mathrm{pH}$ of 2, 4, 6 and 7. Metal uptake by the living biomass was low initially at $\mathrm{pH} 2$ before rising to a maximum value and then dropped slightly at $\mathrm{pH} 6$ and suddenly drops at $\mathrm{pH}$ 7. There was no particular pattern of sorption efficiency with respect to $\mathrm{pH}$ with dead biomass. The highest sorption of $95.27 \%$ (living biomass) and lowest value of $6.71 \%$ (dead biomass) both at $\mathrm{pH} 4$ were obtained for this fungal species. Sorption of lead ion from aqueous solution by live Aspergillus niger was generally better than those of the dead counterpart.

Percentage uptake of $\mathrm{Pb}$ ions by Penicillium austurianum (Figure 3) ranged from $44.47-98.85 \%$ and $75.57-94.21 \%$ for dead and live biomass respectively across the optimised $\mathrm{pH}$. The highest (98.85\%) and lowest sorption (44.47\%) by dead biomass of this fungus was recorded at $\mathrm{pH} 7$ and 4 respectively. Adsorption with respect to $\mathrm{pH}$ was in the order $7>2>6>4$ and $4>2>6>7$ for non-living and living biomass respectively. Appreciable sorption capacities of $(>70 \%)$ of lead ion by both live and dead biomass of Penicillium austurianum was obtained with the exception of $44.47 \%$ (dead biomass) at $\mathrm{pH} 2$.

From Figure 4, the uptake of lead ion by Saccharomyces cerevisiae varied between $52.61-88.68 \%$ and $61.20-89.95 \%$ for dead and live biomasses respectively. Also, the highest sorption of $88.68 \%$ at $\mathrm{pH} 4$ and $89.95 \%$ at $\mathrm{pH} 7$ were obtained for the two forms of the biomass in the same order. Comparable sorption capacities by the two forms (88.68\% and $89.95 \%$ ) of lead ion were demonstrated and the influence of $\mathrm{pH}$ on metal uptake was in the order of $7>$ $6=2>4$ and $4>2>6>7$ for the dead and live biomass respectively of this fungus.

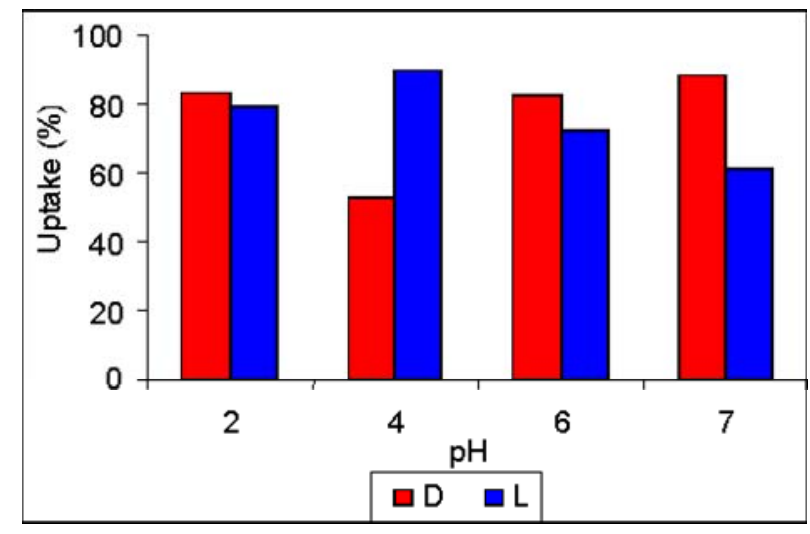

Figure 4. Effect of $\mathrm{pH}$ on uptake of $\mathrm{Pb}$ by Saccharomyces cerevisiae. $\mathrm{Pb}$ concentration, $100 \mathrm{mg} \mathrm{I}^{-1}$; biomass loading at $0.3 \mathrm{~g}, \mathrm{D}=$ dead biomass, $\mathrm{L}=$ live biomass.

The best and consistent uptake of lead ion by the fungal biomass across the optimised $\mathrm{pH}$ was observed with Mucor arcindloides (Figure 5). The percentage uptake ranged from 83.78-93.13\% and 62.91-97.65\% for dead and live biomass respectively. For the dead biomass, the highest uptake was observed at $\mathrm{pH} 7$ while for live biomass, it was at $\mathrm{pH} 2$. A downward trend of metal sorption up the evaluated $\mathrm{pH}$ range was observed with the live biomass while the opposite trend except at $\mathrm{pH} 7$ was noted with the dead biomass of this fungus. The effect of $\mathrm{pH}$ on sorption capacity by this fungus is in the order of $7>2>4>6$ and 2 $>4>6>7$ for dead and live biomass respectively. $\mathrm{pH} 7$ appeared to be optimal and suitable for metal uptake by the dead biomass. In Figure 6, the efficiency of metal sorption by Trichoderma reesi was in the range of $52.52-80.70 \%$ and $35.31-88.13 \%$ also for the dead and live biomass respectively. Again, the highest uptake of lead for dead biomass was observed at $\mathrm{pH} 7$ while that of live was at $\mathrm{pH}$ 2. A regular pattern of sorption efficiency among the dead fungi with respect to $\mathrm{pH}$ was observed. The $\%$ adsorption decreased in the order $\mathrm{pH} 7>2>6>4$ with the exception of Mucor ( $\mathrm{pH} 7>2>4>6$ ). The highest sorption occurred at $\mathrm{pH} 7$. 
$\mathrm{pH}$ changes generally have significant effects on metal solubilities and sorption/desorption reactions i.e. speciation in acidic and basic environment. At low $\mathrm{pH}(<2)$, lead ion tend to form insoluble salts hence would be unavailable in solution for sorption by the biomass. Also, at high $\mathrm{pH}(>9)$, it forms precipitates e.g. lead (II) hydroxide in the presence of sodium hydroxide. Hence, the results obtained from the present study revealed optimal sorption of lead ion at $\mathrm{pH} 7$.

The sorption of metal cations usually occur at $\mathrm{pH}$ close to neutral while desorption is usually carried out by contact with acidic solution (Guibal, 2004). Optimal sorptions of metal ion at $\mathrm{pH} 7$ by fungal biomass have also been reported (Zouboulis et al. 2003; Deng and Ting, 2005). In addition, competition between protons and metal ions for the same sites is known to occur particularly at low $\mathrm{pH}$ values (Fourest and Roux, 1992). Hence in this study, further optimisation of the modified biomass of Aspergillus niger was carried out at $\mathrm{pH} 7$ since better sorption efficiencies were obtained earlier with dead biomass. Live fungal biomass generally recorded better sorption efficiency than the dead counterpart. For practical purposes of metal removal from aqueous media however, dead fungal biomass has always been preferred to the live ones. This is due to earlier mentioned reasons of no toxicity problems, easy desorption of adsorbed metals, reusability of the biomass and non possession of obnoxious odour after usage among other reasons for dead fungal biomass.

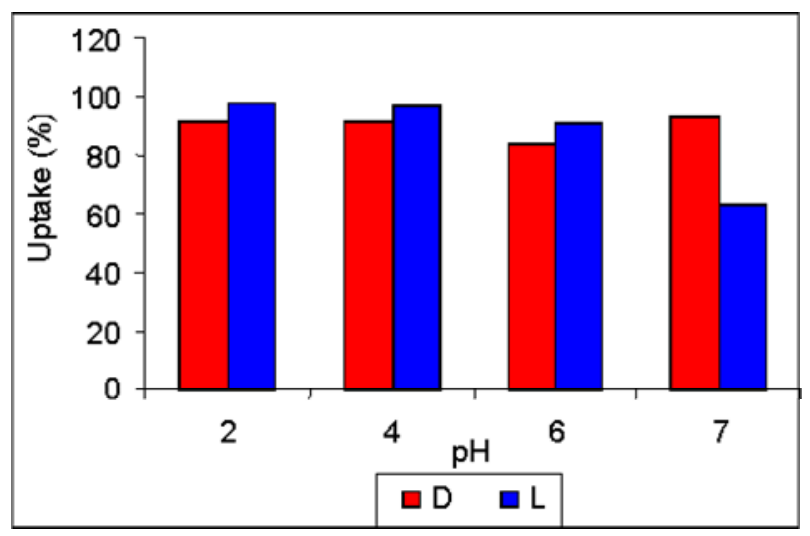

Figure 5. Effect of $\mathrm{pH}$ on uptake of $\mathrm{Pb}$ by Mucor arcindloides. $\mathrm{Pb}$ concentration, $100 \mathrm{mg} \mathrm{I}^{-1}$; biomass loading at $0.3 \mathrm{~g}, \mathrm{D}=$ dead biomass, $\mathrm{L}=$ live biomass.

\section{Modification of dead biomass}

With increasing interest in the application of dead microbial biomass for metal remediation from contaminated water, it became interesting to optimise the dead fungal biomass of Aspergillus niger since it gave the least adsorption efficiency. Results of the percentage uptake of $\mathrm{Pb}$ ion by unmodified and modified biomass of dead Aspergillus niger using oxalic acid, malic acid and EDTA as modifying agents is presented in Table 1. Oxalic acid modified biomass recorded 69.65\% increase in sorption efficiency when compared to that of the unmodified biomass. This performance is comparable to the $92 \%$ removal of lead ion from aqueous solution by modified fungal biomass reported by Liu et al. (2005). Modified biomass using EDTA recorded the lowest sorption when compared with the other two modifying reagents. This could be as a result of the bulkiness of this molecule and also due to the orientation of the hydroxyl and the amine groups within the EDTA structure during the modification. Both oxalic and malic acids possess simpler structures which tend toward some form of linear molecular orientation that could facilitate easy bonding with binding sites (especially amino groups) on the biomass thus increasing the number of sites for metal bonding. Hence, the increase in modifying capacity of the three reagents was in the order: oxalic acid $>$ malic acid $>$ EDTA which was according to the structural complexity of the compounds. Generally, increase in uptake was obtained with the three modifying agents when compared with the unmodified biomass. The percentage uptake of lead ion by modified and unmodified biomass obtained in this study was compared to similar studies (Table 2). 92\% uptake of metal ion by modified fungal biomass reported by Liu et al. (2005) was comparable to the uptake of $92.84 \%$ obtained in this study. The value obtained in this study was better than the uptake of $76.3 \%$ of $\mathrm{Pb}$ ion at optimal $\mathrm{pH}$ of 5 and 100 $\mathrm{mg} \mathrm{l}^{-1}$ of metal loading (Deng and Ting, 2005) and 61.3\% of $\mathrm{Cr}^{6+}$ at $100 \mathrm{mg} \mathrm{l}^{-1}$ of metal loading at $\mathrm{pH} \mathrm{2,} 25 \mathrm{mg}$ mycelia of Lentinus sajor - caju per $7.5 \mathrm{ml}$ reaction medium at $25^{\circ} \mathrm{C}$ (Bayramoglu et al. 2005) reported in similar studies.

\section{New approach to chemical modification of fungal biomass}

Modification of the cell wall and biomass of microorganisms have been explored extensively in attempts to increase the sorption efficiency of metal ions by the biomass using several modifying agents (Brady and Duncan, 1994; Jianlong, 2002; Deng and Ting, 2005). Modification processes of fungal biomasses reported in many literatures are laborious with many reaction steps such as centrifugation, dialysis, usage of cross-linking agents and multiple washing and re-suspension process. Chemical modification of yeast cell wall reported by Brady and Duncan, (1994) involved multiple centrifugation, dialysis, specific reaction condition (under nitrogen gas at $\mathrm{pH}$ 6.8) and washing steps. Glutaraldehyde was used as a cross-linking agent in an effort to improve the sorption capacity of Penicillium chrysogenum during biomass modification using polyethylene imine (PEI) (Deng and Ting, 2005).

Jianlong, (2002) reported a glutaraldehyde fixation to Saccharomyces cerevisiae involving up to 3 days of reaction process followed by filtration, washing and drying for 10 hrs. The additional use of cross-linking agents increases the reaction time and cost of the modification. Although, the cross-linking of $A$. nodosum by divinyl sulfone and formaldehyde under acidic conditions was 
found to reduce the swelling of the biomass so as to be amenable for column adsorption; the cross-linkage also resulted in reduced capacity from $215 \mathrm{mg} \mathrm{Cd} / \mathrm{g}$ for raw biomass to $149 \mathrm{mg} \mathrm{Cd} / \mathrm{g}$ for the formaldehyde-cross linked biomass (Adrian et al. 1999). The use of cationic surfactants, hexadecyl-trimethylammonium bromide and dodecylamine in the modification of the biomass of Penicillium chrysogenum has been reported (Matis et al. 2003). This cationic surfactant replaces cations such $\mathrm{Na}^{+}$, $\mathrm{K}^{+}, \mathrm{Mg}^{2+}$, and $\mathrm{Ca}^{2+}$ present on the biomass surface rendering the surface positive or less negative. This facilitates the sorption of oxyanions and the treatment was found to improve the efficiency of sorption of As (V) by the dead biomass of $P$. chrysogenum. However, hexadecyltrimethylammonium bromide is a toxic and hazardous chemical with severe eyes, skin and respiratory tract irritation. It also affects the gastrointestinal tract with symptoms such as nausea, vomiting and diarrhoea if accidentally ingested. At this juncture, it is pertinent to mention that great emphasis and consideration should be placed in the selection of reagents to be used for biomass modification. In this way, the release of toxic chemicals to the environment would be avoided.

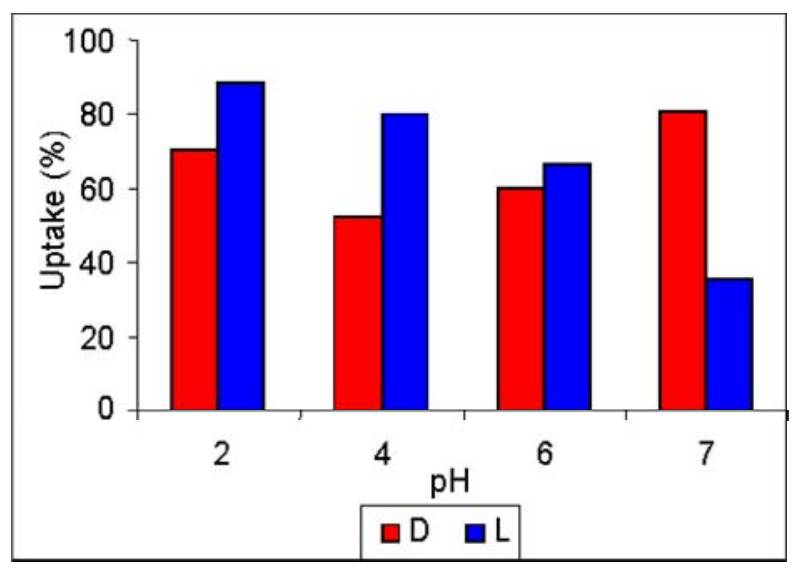

Figure 6. Effect of $\mathrm{pH}$ on uptake of $\mathrm{Pb}$ by Trichoderma reesi. $\mathrm{Pb}$ concentration, $100 \mathrm{mg} \mathrm{I}^{-1}$; biomass loading at $0.3 \mathrm{~g} ; \mathrm{D}=$ dead biomass, $\mathrm{L}=$ live biomass.

In the present study however, a new approach to biomass modification was explored. This involves the use of common, readily available, cheap and most importantly, environmental friendly modifying agents which are oxalic acid, malic acid and EDTA. The modification procedure involves addition of the modifying agent to the powdered biomass which was then dried at low heat of $50^{\circ} \mathrm{C}$ in oven overnight (12 hrs). The biomass is washed using distilled water to remove excess reagent and finally dried at same temperature for a few hours (3-4 hrs) Figure 1. The protocol was found to be simple, fast and efficient. Efficiency and applicability of the modified biomass was revealed by the quantitative adsorption of lead ion from aqueous solution compared with the unmodified biomass. Cost of the adsorbent is an important parameter for consideration in the choice of materials to be used for metal removal from aqueous systems. A sorbent can be assumed or referred to as "low cost" if minimal processing of the material is required, is quite abundant in nature, or is a byproduct or waste material from industrial processes. Aspergillus niger fits into one of these conditions because it could readily be obtained as industrial waste resulting from citric acid production which makes its utilisation both cost effective and environmental friendly. In addition, the proposed modification protocols could be said to be economically viable and worthy given the significant difference in sorption efficiency of $92 \%$ of $\mathrm{Pb}$ ion for the modified biomass compared with $28.12 \%$ of the unmodified using oxalic acid as the modifying agent; a common, cheap and readily available reagent.

\section{CONCLUDING REMARKS}

The ability of fungi species to sorb lead ion from aqueous solution through batch experiments was demonstrated. Quantitative adsorption of lead ion by both live and dead biomass of fungal species was obtained with the exception of dead biomass of Aspergillus niger (6.71\%) at $\mathrm{pH} 2$. A regular pattern of sorption efficiency among the dead fungi species with respect to $\mathrm{pH}$ was observed and the \% adsorption decreased in the order $\mathrm{pH} 7>2>6>4$ with the exception of Mucor ( $\mathrm{pH} 7>2>4>6$ ). A new approach to biomass modification protocol was developed which was found to be simple, fast and efficient with respect to sorption of lead ions from aqueous system. Modification with oxalic acid gave the best sorption efficiency relative to malic acid and EDTA when compared with $28.18 \%$ of the unmodified biomass. The modified biomass of Aspergillus niger and the simplified protocol demonstrate their potential industrial applications for the removal of metals from contaminated water systems.

\section{REFERENCES}

ALDRICH, C. and FENG, D. Adsorption of heavy metals by biomaterials derived from the marine alga Ecklonia maxima. Hydrometallurgy, April 2004, vol. 73, no. 1-2, p. $1-10$.

ATWOOD, David A.; HOWERTON, Brock S. and MATLOCK, Matthew M. Chemical precipitation of heavy metals from acid mine drainage. Water Research, November 2002, vol. 36, no. 19, p. 4757-4764.

ADRIAN, D. Dean; BAILEY, Susan E.; OLIN, Trudy J. and BRICKA, R. Mark. A review of potentially low-cost sorbents for heavy metals. Water Research, August 1999, vol. 33, no. 11, p. 2469-2479.

BAYRAMOGLU, Gülay; CELIK, Gökçe; YALCIN, Emine; YILMAZ, Meltem and ARICA, M. Yakup. Modification of surface properties of Lentinus sajor-caju mycelia by physical and chemical methods: evaluation of their $\mathrm{Cr} 6+$ removal efficiencies from aqueous medium. Journal of Hazardous Materials, March 2005, vol. 119, no. 
1-3, p. 219-229.

BORGMANN, U. Metal Speciation and Toxicity of Free Metal Ions to Aquatic Biota. In: NRIAGU, James O. ed. Aquatic Toxicity (Advances in Environmental Science and Technology. New York, John Wiley and Sons, 1983, p. 4773.

BRADY, D. and DUNCAN, J.R. Binding of heavy metals by the cell walls of Saccharomyces cerevisiae. Enzyme Microbiology Technology, July 1994, vol. 16, no. 7, p. 633638.

CAÑIZARES-VILLANUEVA， R.O.; PEÑA-CASTRO, J.M.; MARTÍNEZ-JERÓNIMO, F. and ESPARZAGARCÍA, F. Heavy metals removal by the microalga Scenedesmus incrassatulus in continuous cultures. Bioresource Technology, September 2004, vol. 94, no. 2, p. 219-222.

CRIST, Ray H. and MARTIN, J. Robert. Interaction of metal ions with acid sites of biosorbent peat moss and Vaucheria and model substances alginic and humic acids. Environmental Science and Technology, July 1999, vol. 33, no. 13, p. 2252-2256.

DENG, Shubo and TING, Yen-Peng. Characterization of PEI-modified biomass and biosorption of $\mathrm{Cu}$ (II), $\mathrm{Pb}$ (II) and Ni (II). Water Research, May 2005, vol. 39, no. 10, p. 2167-2177.

DI PALMA, L.; FERRANTELLI, P.; MERLI, C. and PETRUCCI, E. Treatment of the solution extracted from metal contaminated soils by reverse osmosis and chemical precipitation. Annali di Chimica, December 2003, vol. 93, no. 12, p. 1005-1011.

FOUREST, Eric and ROUX, Jean-Claude. Heavy metal biosorption by fungal mycelial by-products: mechanisms and influence of $\mathrm{pH}$. Applied Microbiology and Biotechnology, June 1992, vol. 37, no. 3, p. 399-403.

GONZÁLEZ-CHÁVEZ M.C.; CARRILLO-GONZÁLEZ, R.; WRIGHT, S.F. and NICHOLS, K.A. The role of glomalin, a protein produced by arbuscular mycorrhizal fungi, in sequestering potentially toxic elements. Environmental Pollution, August 2004, vol. 130, no. 3, p. 317-323.

GUIBAL, Eric. Interactions of metal ions with chitosanbased sorbents: a review. Separation and Purification Technology, July 2004, vol. 38, no. 1, p. 43-74.

HUANG, C. and HUANG, C.P. Application of Aspergillus oryze and Rhizopus oryzae for $\mathrm{Cu}(\mathrm{II})$ removal. Water Research, September 1996, vol. 30, no. 9, p. 1985-1990.

IQBAL, Muhammed; SAEED, Asma and AKHTAR, M. Waheed. Removal and recovery of lead (II) from single and multimetal ( $\mathrm{Cd}, \mathrm{Cu}, \mathrm{Ni}, \mathrm{Zn}$ ) solutions by crop milling waste (black gram husk). Journal of Hazardous Materials, January 2005, vol. 117, no. 1, p. 65-73.

JIANLONG, Wang. Biosorption of copper (II) by chemically modified biomass of Saccharomyces cerevisiae. Process Biochemistry, March 2002, vol. 37, no. 8, p. 847850.

LIU, Zhili; GONG, Renmin; DING, Yi; LIU, Huijun and CHEN, Qiuyi. Lead biosorption and desorption by intact and pre-treated spirulina maxima biomass. Chemosphere, January 2005, vol. 58, no. 1, p. 125-130.

MA, B.-Y.; LI, W.; JING, G.-H. and SHI, Y. Dissimilatory reduction of Fe III (EDTA) with microorganisms in the system of nitric oxide removal from the flue gas by metal chelate absorption. Journal of Environmental Sciences, 2004, vol. 16, no. 3, p. 428-430.

MATIS, Kostas A.; LOUKIDOU, María X.; ZOUBOULIS, Anastasios I. and LIAKOPOULOU-KYRIAKIDOU, María. Removal of As (V) from wastewaters by chemically modified fungal biomass. Water Research, November 2003, vol. 37, no. 18, p. 4544-4552.

NATARAJAN, K.A.; SEKHAR, K.C.; SUBRAMANIAN, S. and MODAK, J.M. Removal of metal ions using an industrial biomass with reference to environmental control. International Journal of Mineral Processes, February 1998, vol. 53, no. 1-2, p. 107-120.

PARK, Jong Moon; PARK, Donghee; YUN, Yeoung-Sang and JO, Ji Hye. Mechanism of hexavalent chromium removal by dead fungal biomass of Aspergillus niger. Water Research, February 2005, vol. 39, no. 4, p. 533-540.

PETERS, Robert W.; YOUNG, $\mathrm{Ku}$ and BHATTACHARYYA, Dibakar. Evaluation of recent treatment techniques for removal of heavy metals from industrial wastewaters. AICHE Symposium Series, September 1985, vol. 81, no. 243, p. 165-203.

REED, Brian E. and NONAVINAKERE, Sujith Kumar. Heavy metal adsorption by activated carbon: Effect of complexing ligands, competing adsorbates, ionic strength, and background electrolyte. Separation Science and Technology, November 1992, vol. 27, no. 14, p. 1985-2000.

ROSTAMI, K.H. and JOODAKI, M.R. Some studies of cadmium adsorption using Aspergillus niger, Penicillium austurianum, employing an airlift fermenter. Chemical Engineering Journal, October 2002, vol. 89, no. 1-3, p. 239-252.

SAG, Yesim and KUTSAL, Tülin. The selective biosorption of chromium (VI) and copper (II) ions from binary metal mixtures by $R$. arrhizus. Process Biochemistry, August 1996, vol. 31, no. 6, p. 561-572. 
THOMAS, C.R.; AMANULLAH, A.; JUSTEN, P.; DAVIES, A.; PAUL, G.C. and NIENOW, A.W. Agitation induced mycelial fragmentation of Aspergillus oryzae and Penicillium chrysogenum. Biochemical Engineering Journal, June 2000, vol. 5, no. 2, p. 109-114.

TYLER, T.G. Heavy metals in soil biology and biochemistry. In: Soil Biochemistry. New York, Marcel Dekker, 1981, p. 22-23.

VEGLIO, F. and BEOLCHINI, F. Removal of metals by biosorption: a review. Hydrometallurgy, March 1997, vol. 44, no. 3, p. 301-316.

VIRARAGHAVAN, Thiruvenkatachari and YAN, Guangyu. Heavy-metal removal from aqueous solution by fungus Mucor rouxii. Water Research, November 2003, vol. 37, no. 18, p. 4486-4496.

WEI, M. and TOBIN, J.M. Determination and modelling of effects of $\mathrm{pH}$ on peat biosorption of chromium, copper and cadmium. Biochemical Engineering Journal, April 2004, vol. 18, no. 1, p. 33-40.

WILHELMI, B.S. and DUNCAN, J.R. Metal recovery from Saccharomyces cerevisiae biosorption columns. Biotechnology Letters, September 1995, vol. 17, no. 9, p. 1007-1012.

YIN, Pinghe; YU, Qiming; JIN, Bo and LING, Zhao. Biosorption removal of cadmium from aqueous solution by using pretreated fungal biomass cultured from starch wastewater. Water Research, June 1999, vol. 33, no. 8, p. 1960-1963.

ZOUBOULIS, A.I.; LOUKIDOU, M.X. and MATIS, K.A. Biosorption of toxic metals from aqueous solutions by bacteria strains isolated from metal-polluted soils. Process Biochemistry, April 2004, vol. 39, no. 8, p. 909-916.

ZOUBOULIS, Anastasios I.; MATIS, Kostas A.; LOUKIDOU, Maria and ŠEBESTA, Ferdinand. Metal biosorption by PAN-immobilized fungal biomass in simulated wastewaters. Colloids and Surfaces A: Physicochemical and Engineering Aspects, January 2003, vol. 212, no. 2-3, p. 185-195. 